ISSN 1678-3921

Journal homepage: www.embrapa.br/pab

For manuscript submission and journal contents, access: www.scielo.br/pab
Stefanie Lais Kreutz Rosa ${ }^{(1 凶)}(0$, Jorge Luiz Moretti de Souza(1) $(0)$ and Rodrigo Yoiti Tsukahara ${ }^{(2)}$ (b)

(1) Universidade Federal do Paraná, Departamento de Solos e Engenharia Agrícola, Rua dos Funcionários, no 1.540 , CEP 80035-050 Curitiba, PR, Brazil. E-mail: skreutzrosa@gmail.com, jmoretti@ufpr.br

(2) Fundação ABC, Rodovia PR 151, Km 288, Caixa Postal 1003, CEP 84166-981 Castro, PR, Brazil.

E-mail: rodrigo@fundacaoabc.org

$\bowtie$ Corresponding author

Received

January 21, 2019

Accepted

October 8, 2019

How to cite

ROSA, S.L.K.; SOUZA, J.L.M. de;

TSUKAHARA, R.Y. Performance of the AquaCrop model for the wheat crop in the subtropical zone in Southern Brazil. Pesquisa Agropecuária Brasileira, v.55, e01238, 2020. DOI: https://doi.org/10.1590/S1678-3921. pab2020.v55.01238.

\section{Performance of the AquaCrop model for the wheat crop in the subtropical zone in Southern Brazil}

\begin{abstract}
The objective of this work was to calibrate and validate the AquaCrop model for the wheat (Triticum aestivum) crop in the Campos Gerais region, in Southern Brazil. Five cultivars were evaluated in the harvests from 2007 to 2017. The input data for AquaCrop - related to climate, crop, soil, and soil management -, collected in the field, were obtained from the database of Fundação ABC and from the literature. From 35 to $43 \%$ of total harvests were selected for calibration, and the remaining, for validation. Calibration was performed for the parameters most sensitive to crop potential yield penalty. The simulated yields were compared with those observed in the field through simple linear regression analysis, root mean square error (RMSE), Pearson's correlation coefficient (r), the index of agreement (d), and the performance index (c). Calibration showed good results (RMSE $\leq 609.78 \mathrm{~kg} \mathrm{ha}^{-1} ; \mathrm{r} \geq 0.72$; $\mathrm{d} \geq 0.80$ ) for all assessed cultivars and locations, but validation did not have the same performance $(c \leq 0.46)$. The attempted adjustment, considering the range of calibrated parameters in the harvests, indicated "very good" and "excellent" performances (Supera and Quartzo, respectively) for the cultivars in Castro and "tolerable" to "excellent" in Ponta Grossa.
\end{abstract}

Index terms: Triticum aestivum, crop yield, mathematical modeling.

\section{Desempenho do modelo AquaCrop para a cultura do trigo na zona subtropical no Sul do Brasil}

Resumo - O objetivo deste trabalho foi calibrar e validar o modelo AquaCrop para a cultura de trigo (Triticum aestivum) na região dos Campos Gerais, no Sul do Brasil. Foram avaliadas cinco cultivares nas safras de 2007 a 2017. Os dados de entrada no AquaCrop - referentes a clima, cultura, solo e manejo do solo -, coletados em campo, foram obtidos do banco de dados da Fundação $\mathrm{ABC}$ e da literatura. De 35 a $43 \%$ do total das safras foram selecionadas para calibração, e as demais, para validação. A calibração foi realizada para os parâmetros mais sensíveis à penalização da produtividade potencial da cultura. As produtividades simuladas foram comparadas às observadas em campo por meio de análises de regressão linear simples, raiz quadrada do erro médio (RMSE), coeficiente de correlação de Pearson (r), índice de concordância (d) e índice de desempenho (c). A calibração apresentou bons resultados (RMSE $\leq$ $609,78 \mathrm{~kg} \mathrm{ha}^{-1} ; \mathrm{r} \geq 0,72 ; \mathrm{d} \geq 0,80$ ) para todas as cultivares e locais avaliados, mas a validação não teve o mesmo desempenho $(c \leq 0,46)$. $O$ ajuste por tentativa, tendo-se considerado a faixa de parâmetros calibrados nas colheitas, indicou desempenhos "muito bom" e "excelente" (Supera e Quartzo, respectivamente) para as cultivares em Castro, e "ruim" a "excelente" em Ponta Grossa.

Termos para indexação: Triticum aestivum, produtividade da cultura, modelagem matemática. 


\section{Introduction}

Wheat (Triticum aestivum L.) is widely cultivated worldwide (FAO, 2018a). In Brazil, the use of wheat cultivars with a high potential productivity, combined with the country's soil and climatic conditions, promotes high yields and crop expansion (Silva et al., 2014). In the state of Paraná, the winter crop is the most important, reaching about 1.081 million hectares of planted area in the 2015/2016 harvest, with a production of 3.3 million tons (Oliveira Neto \& Santos, 2017). The Campos Gerais region stands out in the state due to its agricultural potential, which is above the national average (Shimandeiro et al., 2008).

Campos Gerais is located in the Southeastern and Southern regions of Brazil. It presents a territory band of $11,761.41 \mathrm{~km}^{2}$ with a northwest convexity (Melo et al., 2014). The predominant climate is $\mathrm{Cfa}$ and $\mathrm{Cfb}$ according to the climate map for the country based on Köppen's classification (Alvares et al., 2013). The region is characterized by agriculture focused mainly on grain production in the no-tillage system (Melo et al., 2014).

Understanding the soil-plant-atmosphere system through modeling has been increasingly important for researchers (Jin et al., 2014). However, the highest difficulty in carrying out simulations consists in the collection or availability of input data, which are generally difficult and costly to obtain. Searching for solutions to these limitations, the Food and Agriculture Organization (FAO) developed the AquaCrop model (Raes et al., 2018b).

AquaCrop is a simulation model that describes the interaction between soil and plants, presenting good results, with a high accuracy. It requires few input parameters, which are explicit and intuitive (Foster et al., 2017), obtained easily and at a low cost. In addition, the model is able to simulate accurately biomass production and crop yield under different water content and fertility conditions (Jin et al., 2014).

To increase the reliability and reduce the uncertainties of a model, the used parameters must be subjected to a calibration process (He et al., 2017), which consists in adjusting the input parameter value so that the simulated results in the software are similar to those observed in the field. The next step is the validation process, considering the quality of the output data (Xiangxiang et al., 2013), which indicates if the calibration was adequate under the studied conditions.
The AquaCrop model has been calibrated and validated for several crops and locations, and its accuracy has been widely confirmed (Darko et al., 2016; Montoya et al., 2016; Oiganji et al., 2016; Pareek et al., 2017; Silva et al., 2018). However, there are no researches that prove its efficiency in simulating wheat yield under Brazilian conditions. Despite this, due to its high precision, simplicity and robustness (Raes et al., 2018a), it is believed that AquaCrop can accurately simulate wheat yield in the Campos Gerais region.

The objective of this work was to calibrate and validate the AquaCrop model, developed by FAO, for the wheat crop in the Campos Gerais region, in Southern Brazil.

\section{Materials and Methods}

The study was carried out using climate and wheat crop data obtained in the municipalities of Castro and Ponta Grossa, located in the Campos Gerais region, in the state of Paraná, in the subtropical zone of Southern Brazil, from 2007 to 2017. The analyzed cultivars were: Quartzo, Supera, TBIO Sinuelo, TBIO Tibagi, and TBIO Toruk, cultivated under field conditions, with fertilization and phytosanitary control performed by Fundação ABC (Castro, PR, Brazil), as required for wheat crops.

According to Köppen's climate classification for Brazil (Alvares et al., 2013), Castro is classified as Cfa, a humid subtropical, oceanic climate without dry season and with a hot summer; and Ponta Grossa is classified as $\mathrm{Cfb}$, a humid subtropical, oceanic climate without dry season and with a temperate summer. The pluvial precipitation $(\mathrm{mm})$ and medium daily air temperature $\left({ }^{\circ} \mathrm{C}\right)$ of the analyzed locations are shown in Figure 1.

The used model was AquaCrop, version 6.0 (FAO, 2018b). The climate, crop, and management data were obtained from the database of Fundação ABC (Castro, PR, Brazil), which follows the recommendations for sensors of American Society of Agricultural and Biological Engineers (St. Joseph, MI, USA).

The climatic data inserted in AquaCrop, obtained from the agrometeorological stations installed in the respective study locations, were: pluvial precipitation (mm per day); maximum, minimum, and medium daily air temperature $\left({ }^{\circ} \mathrm{C}\right)$; incident solar radiation $\left(\mathrm{MJ} \mathrm{m}^{-2}\right.$ per day); relative humidity (\%); and wind speed $\left(\mathrm{m} \mathrm{s}^{-1}\right)$. 
The soil fertility level was considered as non-limiting to crop development, and canopy cover was made up of $75 \%$ organic plant materials. The management adopted in the experimental areas did not affect surface runoff, and there was no presence of weeds.

Wheat phenological stages were considered achieved when the cultivars reached the following Zadoks decimal codes (Zadoks et al., 1974): 09, emergence, with leaf just at coleoptile tip; 54, maximum coverage, with half of the inflorescences emerged; 60 , flowering, beginning of anthesis; 60 to 68 , flowering duration; 71, senescence, with kernel watery ripe; and 91, maturity, with kernel hard.

Soil data from Ponta Grossa were collected in the field and analyzed according to Teixeira et al. (2017) (Table 1), while data from Castro were obtained from an experiment carried out in the same area by
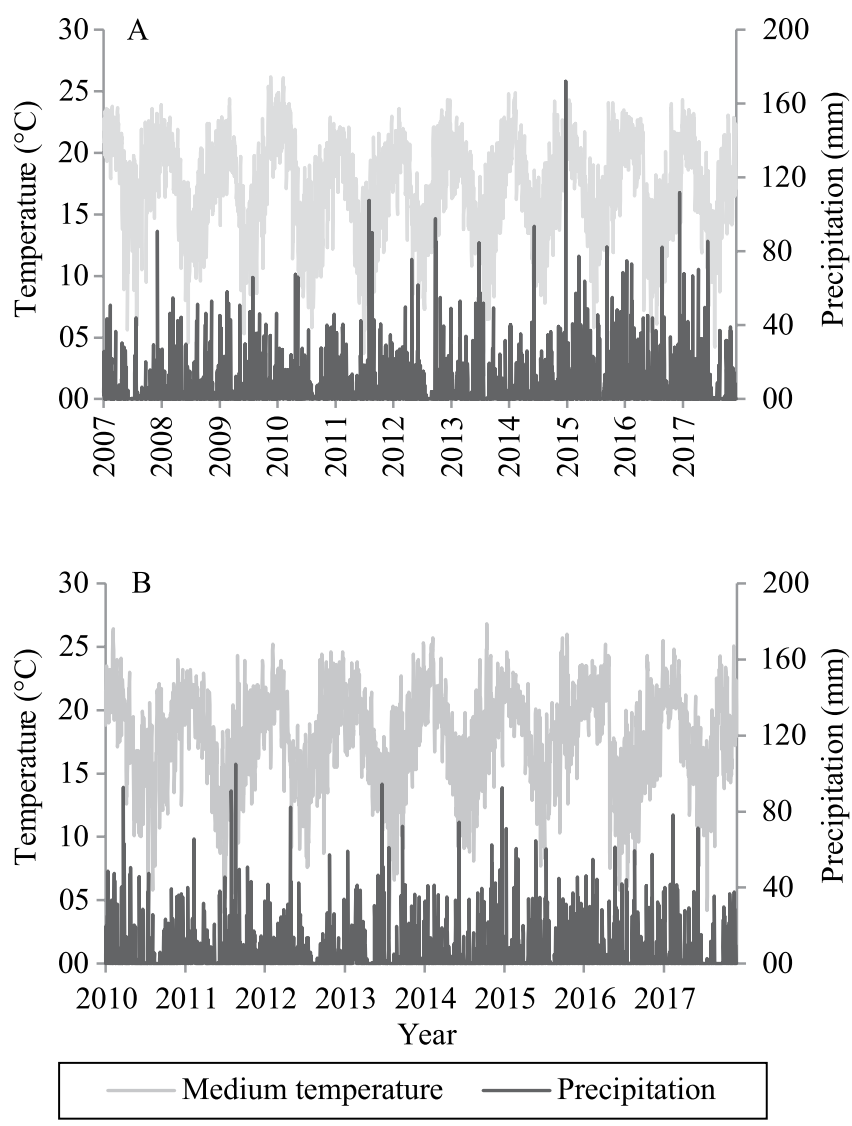

Figure 1. Pluvial precipitation and medium daily air temperature of the experimental locations (municipalities), in the state of Paraná, Southern Brazil: A, Castro; and B, Ponta Grossa.
Piekarski et al. (2017). The initial soil water content was considered equal to the total available soil water in the root zone, which consists in the difference between the water content at field capacity and permanent wilting point, selected in AquaCrop.

The calibration of AquaCrop was performed for the most sensitive parameters identified in Castro and Ponta Grossa, which were: maximum canopy cover (CCx, \%), dependent on environment and/or management, calibrated in Castro and Ponta Grossa; canopy decline coefficient (CDC, percentage per day), conservative and calibrated only in Castro; crop coefficient when the canopy is complete but prior to senescence ( $\mathrm{Kc}_{\mathrm{TR}, \mathrm{x}}$, unitless), also conservative and calibrated both in Castro and Ponta Grossa; normalized water productivity (WP*) for reference evapotranspiration and $\mathrm{CO}_{2}\left(\mathrm{~g} \mathrm{~m}^{-2}\right)$, conservative and calibrated in Castro and Ponta Grossa; reference harvest index $\left(\mathrm{HI}_{\mathrm{o}}, \%\right)$, cultivar specific and also calibrated in Castro and Ponta Grossa; and minimum growing degrees required for full biomass production $\left({ }^{\circ} \mathrm{C}\right.$ per day), conservative and calibrated only in Ponta Grossa. Of the total harvests, 35 to $43 \%$ were randomly selected for calibration in the evaluated municipalities (Table 2). The parameters that did not receive calibration were defined according to the recommendation of Raes et al. (2018a) for wheat crops.

For each simulation, the initial canopy cover at $90 \%$ emergence was automatically determined by AquaCrop, based on the number of plants per hectare inserted in the software, which followed the protocols of Fundação ABC. The minimum and maximum effective rooting depths were 0.1 and $0.3 \mathrm{~m}$, respectively. The canopy growth coefficient (percentage per day) was automatically adjusted in AquaCrop, established on the date of maximum canopy expansion, which was indirectly determined based on the phenological cycle. As the cycle considered in the present study was in days after planting, the value of $8.0 \%$ per day was adopted for the CDC.

After the calibration of the most sensitive AquaCrop parameters, validation was carried out with harvests that were not used in calibration (Table 2). However, the used soil and soil management data were the same for both processes, and the parameter values obtained in calibration were also used for the validation analyzes for each cultivar and location. 
Table 1. Soil physical-hydraulic attributes of the experimental locations inserted in the AquaCrop model for calibration and validation.

\begin{tabular}{|c|c|c|c|c|c|c|}
\hline \multirow{2}{*}{$\begin{array}{l}\text { Location } \\
\text { (Brazilian municipality) }\end{array}$} & \multirow[t]{2}{*}{ Soil layer (m) } & \multirow[t]{2}{*}{ Soil texture } & \multicolumn{3}{|c|}{ Soil water content $\left(\mathrm{m}^{3} \mathrm{~m}^{-3}\right)^{(1)}$} & \multirow{2}{*}{$\begin{array}{c}\mathrm{K}_{\text {sat }}^{(2)} \\
\text { (mm per day) }\end{array}$} \\
\hline & & & $\theta_{\mathrm{PWP}}$ & $\theta_{\mathrm{FC}}$ & $\theta_{\text {Sat }}$ & \\
\hline Castro & $0.00-0.10$ & Clay & 0.36 & 0.50 & 0.63 & 418.32 \\
\hline Castro & $0.10-0.25$ & Clay & 0.33 & 0.47 & 0.60 & 368.23 \\
\hline Castro & $0.25-0.40$ & Clay & 0.32 & 0.45 & 0.62 & 325.74 \\
\hline Ponta Grossa & $0.00-0.10$ & Clay & 0.23 & 0.41 & 0.59 & 469.41 \\
\hline Ponta Grossa & $0.10-0.25$ & Clay & 0.25 & 0.38 & 0.53 & 89.48 \\
\hline Ponta Grossa & $0.25-0.40$ & Clay & 0.23 & 0.41 & 0.62 & 433.84 \\
\hline
\end{tabular}

${ }^{(1)} \theta_{\mathrm{PWP}}$, volumetric water content at wilting point; $\theta_{\mathrm{FC}}$, volumetric water content at field capacity; and $\theta_{\mathrm{Sat}}$, volumetric water content at saturation. ${ }^{(2)}$ Saturated hydraulic conductivity.

Table 2. Experiments, harvests, early and later planting and harvesting dates, lower and higher grain yields, and finality (calibration or validation) of the wheat (Triticum aestivum) cultivars evaluated with the AquaCrop model, in the municipalities of Castro and Ponta Grossa, in the state of Paraná, Southern Brazil, from 2007 to 2017.

\begin{tabular}{|c|c|c|c|c|c|c|}
\hline Location & Cultivar & Harvest & Planting date & Harvesting date & $\begin{array}{l}\text { Grain yield } \\
\left(\mathrm{kg} \mathrm{ha}^{-1}\right)\end{array}$ & Finality \\
\hline \multirow{2}{*}{ Castro } & Supera & 6 & $\begin{array}{l}06 / 15 \text { (early) } \\
07 / 12 \text { (later) }\end{array}$ & $\begin{array}{l}\text { 10/24 (early) } \\
11 / 26 \text { (later) }\end{array}$ & $\begin{array}{l}4,186 \text { (lower) } \\
5,187 \text { (higher) }\end{array}$ & Calibration \\
\hline & Quartzo & 8 & $\begin{array}{l}06 / 05 \text { (early) } \\
07 / 16 \text { (later) }\end{array}$ & $\begin{array}{l}11 / 11 \text { (early) } \\
12 / 03 \text { (later) }\end{array}$ & $\begin{array}{l}\text { 3,903 (lower) } \\
\text { 4,818 (higher) }\end{array}$ & Calibration \\
\hline \multirow{5}{*}{ Ponta Grossa } & Supera & 5 & $\begin{array}{c}\text { 06/04 (early) } \\
07 / 17 \text { (later) }\end{array}$ & $\begin{array}{l}\text { 10/09 (early) } \\
11 / 14 \text { (later) }\end{array}$ & $\begin{array}{l}\text { 3,886 (lower) } \\
5,299 \text { (higher) }\end{array}$ & Calibration \\
\hline & Quartzo & 10 & $\begin{array}{l}05 / 25 \text { (early) } \\
07 / 17 \text { (later) }\end{array}$ & $\begin{array}{l}10 / 16 \text { (early) } \\
11 / 20 \text { (later) }\end{array}$ & $\begin{array}{l}\text { 3,604 (lower) } \\
4,909 \text { (higher) }\end{array}$ & Calibration \\
\hline & TBIO Tibagi & 3 & $\begin{array}{l}06 / 11 \text { (early) } \\
07 / 17 \text { (later) }\end{array}$ & $\begin{array}{l}\text { 10/27 (early) } \\
11 / 14 \text { (later) }\end{array}$ & $\begin{array}{l}\text { 4,001 (lower) } \\
4,686 \text { (higher) }\end{array}$ & Calibration \\
\hline & TBIO Sinuelo & 7 & $\begin{array}{l}05 / 25 \text { (early) } \\
07 / 10 \text { (later) }\end{array}$ & $\begin{array}{l}\text { 10/16 (early) } \\
11 / 28 \text { (later) }\end{array}$ & $\begin{array}{l}\text { 4,006 (lower) } \\
5,432 \text { (higher) }\end{array}$ & Calibration \\
\hline & TBIO Toruk & 3 & $\begin{array}{l}05 / 12 \text { (early) } \\
06 / 03 \text { (later) }\end{array}$ & $\begin{array}{l}\text { 10/05 (early) } \\
10 / 16 \text { (later) }\end{array}$ & $\begin{array}{l}\text { 3,354 (lower) } \\
5,542 \text { (higher) }\end{array}$ & Calibration \\
\hline \multirow{2}{*}{ Castro } & Supera & 10 & $\begin{array}{c}05 / 31 \text { (early) } \\
07 / 17 \text { (later) }\end{array}$ & $\begin{array}{l}10 / 24 \text { (early) } \\
11 / 26 \text { (later) }\end{array}$ & $\begin{array}{l}\text { 2,043 (lower) } \\
5,880 \text { (higher) }\end{array}$ & Validation \\
\hline & Quartzo & 15 & $\begin{array}{l}05 / 31 \text { (early) } \\
07 / 16 \text { (later) }\end{array}$ & $\begin{array}{l}10 / 30 \text { (early) } \\
12 / 01 \text { (later) }\end{array}$ & $\begin{array}{l}\text { 3,104 (lower) } \\
6,206 \text { (higher) }\end{array}$ & Validation \\
\hline \multirow{5}{*}{ Ponta Grossa } & Supera & 8 & $\begin{array}{l}06 / 06 \text { (early) } \\
07 / 10 \text { (later) }\end{array}$ & $\begin{array}{l}\text { 10/22 (early) } \\
11 / 11 \text { (later) }\end{array}$ & $\begin{array}{l}\text { 2,293 (lower) } \\
5,968 \text { (higher) }\end{array}$ & Validation \\
\hline & Quartzo & 19 & $\begin{array}{l}05 / 12 \text { (early) } \\
07 / 22 \text { (later) }\end{array}$ & $\begin{array}{l}10 / 05 \text { (early) } \\
11 / 26 \text { (later) }\end{array}$ & $\begin{array}{l}\text { 1,631 (lower) } \\
6,360 \text { (higher) }\end{array}$ & Validation \\
\hline & TBIO Tibagi & 5 & $\begin{array}{l}06 / 04 \text { (early) } \\
07 / 10 \text { (later) }\end{array}$ & $\begin{array}{l}\text { 10/09 (early) } \\
11 / 08 \text { (later) }\end{array}$ & $\begin{array}{l}\text { 3,367 (lower) } \\
6,010 \text { (higher) }\end{array}$ & Validation \\
\hline & TBIO Sinuelo & 13 & $\begin{array}{l}05 / 12 \text { (early) } \\
07 / 22 \text { (later) }\end{array}$ & $\begin{array}{l}\text { 10/05 (early) } \\
11 / 18 \text { (later) }\end{array}$ & $\begin{array}{l}\text { 2,891 (lower) } \\
6,100 \text { (higher) }\end{array}$ & Validation \\
\hline & TBIO Toruk & 4 & $\begin{array}{l}06 / 03 \text { (early) } \\
07 / 22 \text { (later) }\end{array}$ & $\begin{array}{l}10 / 16 \text { (early) } \\
11 / 18 \text { (later) }\end{array}$ & $\begin{array}{l}\text { 3,506 (lower) } \\
\text { 4,492 (higher) }\end{array}$ & Validation \\
\hline
\end{tabular}


Yields $\left(\mathrm{kg} \mathrm{ha}^{-1}\right)$ were simulated by the calibration and validation processes in AquaCrop and compared with the real yields observed in the field $\left(\mathrm{kg} \mathrm{ha}^{-1}\right)$, using a simple linear regression analysis. The absolute and relative errors, root mean square error (RMSE) (Jacovides \& Kontoyiannis, 1995), Pearson's correlation coefficient (r), and index of agreement (d) (Willmott, 1982) were also used to compare simulated to real data. For the validation process, performance was calculated with the $\mathrm{c}$ index, proposed by Camargo \& Sentelhas (1997), and was classified as: "excellent", c $>0.85$; "very good", $0.75<\mathrm{c} \leq 0.85$; "good", 0.65 $<\mathrm{c} \leq 0.75$; "medium", $0.60<\mathrm{c} \leq 0.65$; "tolerable", $0.50<\mathrm{c} \leq 0.60$; "bad", $0.40<\mathrm{c} \leq 0.50$; and "terrible", $\mathrm{c} \leq 0.40$.

\section{Results and Discussion}

The values obtained in the calibration process for the most sensitive AquaCrop parameters in Castro and Ponta Grossa are shown in Table 3. The regression analysis between real and simulated yields presented excellent results in calibration (Figure 2) according to Akoglu (2018), with Pearson's correlation coefficient ranging from 0.72 to 0.92 , the $\mathrm{d}$ index from 0.80 to 0.94 , and RMSE from 150.40 to $609.78 \mathrm{~kg} \mathrm{ha}^{-1}$ (Table 4). Kumar et al. (2014) found better adjustments for wheat with AquaCrop at different levels of soil salinity in Delhi $(r=0.99$ and $d=0.99)$. Good adjustments were also reported by Toumi et al. (2016) in Morocco ( $\mathrm{r}=$ 0.99 and $\mathrm{RMSE}=30 \mathrm{~kg} \mathrm{ha}^{-1}$ ), considering $\mathrm{HI}_{\mathrm{o}}=46 \%$ and $\mathrm{WP}^{*}=16 \mathrm{~g} \mathrm{~m}^{-2}$.

Table 3. Values of the parameters used in the calibration process by the AquaCrop model for wheat (Triticum aestivum) cultivars, in the municipalities of Castro and Ponta Grossa, in the state of Paraná, Southern Brazil.

\begin{tabular}{|c|c|c|c|c|c|}
\hline \multirow[t]{2}{*}{ Parameter } & \multicolumn{5}{|c|}{ Cultivar } \\
\hline & Supera & Quartzo & TBIO Sinuelo & TBIO Tibagi & TBIO Toruk \\
\hline & \multicolumn{5}{|c|}{ Castro } \\
\hline $\mathrm{CC}_{\mathrm{x}}(\%)^{(1)}$ & $\begin{array}{c}93^{(6)} \\
(80 \text { to } 92)^{(7)}\end{array}$ & $\begin{array}{c}89^{(6)} \\
(86 \text { to } 93)^{(7)}\end{array}$ & - & - & - \\
\hline $\mathrm{Kc}_{\mathrm{TR}, \mathrm{x}}$ (unitless) $)^{(2)}$ & $\begin{array}{c}1.37^{(6)} \\
(1.05 \text { to } 1.4)^{(7)}\end{array}$ & $\begin{array}{c}1.3^{(6)} \\
(1.25 \text { to } 1.35)^{(7)}\end{array}$ & - & - & - \\
\hline WP $\left(\mathrm{g} \mathrm{m}^{-2}\right)^{(3)}$ & $\begin{array}{c}18^{(6)} \\
(16 \text { to } 20)^{(7)}\end{array}$ & $\begin{array}{c}17^{(6)} \\
(17 \text { to } 19)^{(7)}\end{array}$ & - & - & - \\
\hline $\mathrm{HI}_{\mathrm{o}}(\%)^{(4)}$ & $\begin{array}{c}62^{(6)} \\
(46 \text { to } 70)^{(7)}\end{array}$ & $\begin{array}{c}56^{(6)} \\
(48 \text { to } 65)^{(7)}\end{array}$ & - & - & - \\
\hline \multirow[t]{2}{*}{ CDC (\% per day $)^{(5)}$} & $\begin{array}{c}7.6^{(6)} \\
(7.2 \text { to } 8.4)^{(7)}\end{array}$ & $\begin{array}{c}7.7^{(6)} \\
(7.1 \text { to } 8.3)^{(7)}\end{array}$ & - & - & - \\
\hline & \multicolumn{5}{|c|}{ Ponta Grossa } \\
\hline $\mathrm{CC}_{\mathrm{x}}(\%)^{(1)}$ & $\begin{array}{c}90^{(6)} \\
(83 \text { to } 89)^{(7)}\end{array}$ & $\begin{array}{c}89^{(6)} \\
(76 \text { to } 92)^{(7)}\end{array}$ & $\begin{array}{c}90^{(6)} \\
(82 \text { to } 90)^{(7)}\end{array}$ & $\begin{array}{c}90^{(6)} \\
(90 \text { to } 92)^{(7)}\end{array}$ & $\begin{array}{c}89^{(6)} \\
(82 \text { to } 89)^{(7)}\end{array}$ \\
\hline $\mathrm{Kc}_{\mathrm{TR}, \mathrm{x}}$ (unitless) $^{(2)}$ & $\begin{array}{c}1.3^{(6)} \\
(1.0 \text { to } 1.35)^{(7)}\end{array}$ & $\begin{array}{c}1.25^{(6)} \\
(0.95 \text { to } 1.3)^{(7)}\end{array}$ & $\begin{array}{c}1.25^{(6)} \\
(0.95 \text { to } 1.4)^{(7)}\end{array}$ & $\begin{array}{c}1.25^{(6)} \\
(1.2 \text { to } 1.35)^{(7)}\end{array}$ & $\begin{array}{c}1.35^{(6)} \\
(1.05 \text { to } 1.4)^{(7)}\end{array}$ \\
\hline $\mathrm{WP}\left(\mathrm{g} \mathrm{m}^{-2}\right)^{(3)}$ & $\begin{array}{c}18^{(6)} \\
(16 \text { to } 19)^{(7)}\end{array}$ & $\begin{array}{c}17^{(6)} \\
(14 \text { to } 19)^{(7)}\end{array}$ & $\begin{array}{c}17^{(6)} \\
(15 \text { to } 19)^{(7)}\end{array}$ & $\begin{array}{c}17^{(6)} \\
(16 \text { to } 19)^{(7)}\end{array}$ & $\begin{array}{c}19^{(6)} \\
(15 \text { to } 19)^{(7)}\end{array}$ \\
\hline $\mathrm{HI}_{\mathrm{o}}(\%)^{(4)}$ & $\begin{array}{c}56^{(6)} \\
(45 \text { to } 49)^{(7)}\end{array}$ & $\begin{array}{c}55^{(6)} \\
(35 \text { to } 64)^{(7)}\end{array}$ & $\begin{array}{c}56^{(6)} \\
(44 \text { to } 58)^{(7)}\end{array}$ & $\begin{array}{c}58^{(6)} \\
(51 \text { to } 63)^{(7)}\end{array}$ & $\begin{array}{c}57^{(6)} \\
(46 \text { to } 57)^{(7)}\end{array}$ \\
\hline $\begin{array}{l}\text { Minimum growing degree } \\
\text { required for biomass } \\
\text { production }\left({ }^{\circ} \mathrm{C} \text { per day }\right)^{(6)}\end{array}$ & $\begin{array}{c}13.8^{(6)} \\
(13.9 \text { to } 15)^{(7)}\end{array}$ & $\begin{array}{c}16^{(6)} \\
(12.1 \text { to } 16)^{(7)}\end{array}$ & $\begin{array}{c}14.9^{(6)} \\
(14.6 \text { to } 15.2)^{(7)}\end{array}$ & $\begin{array}{c}15.5^{(6)} \\
(14.7 \text { to } 15.5)^{(7)}\end{array}$ & $\begin{array}{c}15.2^{(6)} \\
(15.1 \text { to } 15.2)^{(7)}\end{array}$ \\
\hline
\end{tabular}


Both the absolute and relative errors obtained in the calibration of the wheat cultivars with AquaCrop, in all analyzed locations, were small (Table 4). The largest RMSE was observed in Ponta Grossa for the TBIO Toruk cultivar; however, this error was still considered small compared with the real yield of the assessed variable.
The $\mathrm{HI}_{\mathrm{o}}$ was $62 \%$ for cultivar Supera and $56 \%$ for Quartzo in Castro. In Ponta Grossa, the values of this index ranged from 55 to $58 \%$ for the different cultivars. According to Raes et al. (2018a), the recommended $\mathrm{HI}_{\mathrm{o}}$ for the wheat crop should range from 45 to $50 \%$; however, in the present study, the obtained values were higher. It should be noted that $\mathrm{HI}_{\mathrm{o}}$ is a cultivar-specific
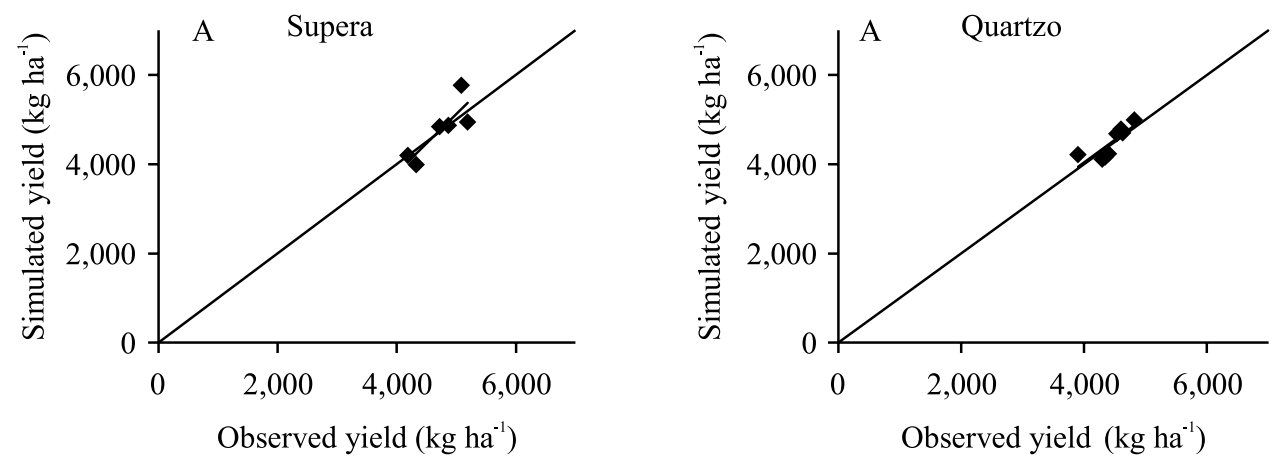

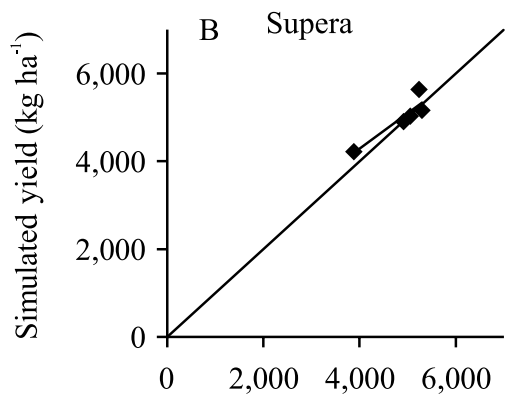

Observed yield $\left(\mathrm{kg} \mathrm{ha}^{-1}\right)$

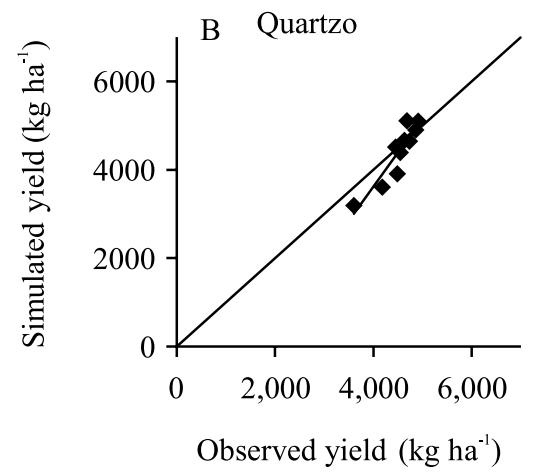

Observed yield $\left(\mathrm{kg} \mathrm{ha}^{-1}\right)$

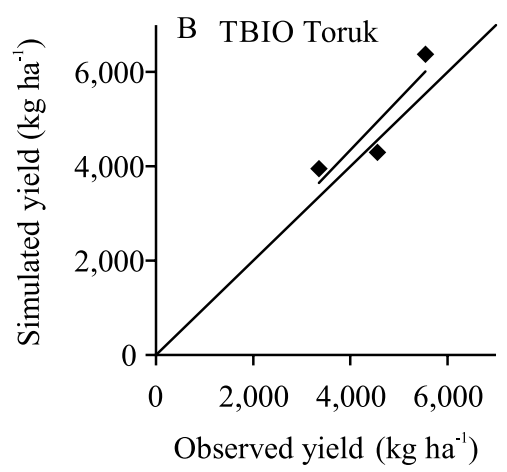

Observed yield $\left(\mathrm{kg} \mathrm{ha}^{-1}\right)$
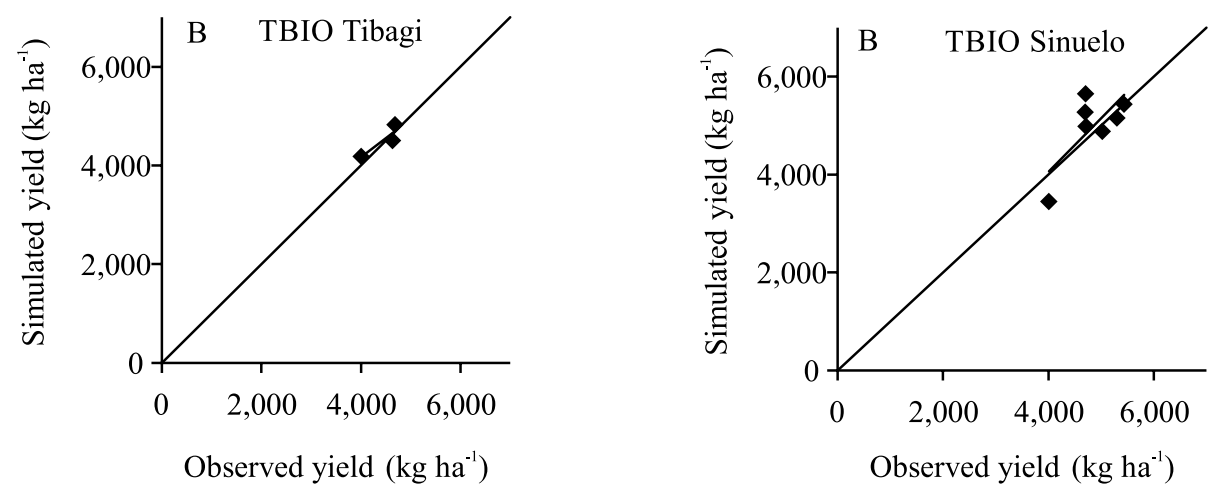

Figure 2. Linear regression analysis obtained from the association of simulated vs. observed yield in the calibration process by the AquaCrop model for wheat (Triticum aestivum) cultivars evaluated in the municipalities of Castro (A) and Ponta Grossa (B) in the state of Paraná, Southern Brazil. 
parameter (Raes et al., 2018a), and its value may vary under different cultivation conditions or water regimes. Bouazzama et al. (2017) and Toumi et al. (2016) found $\mathrm{HI}_{\mathrm{o}}=46 \%$ in Morocco, Andarzian et al. (2011) $\mathrm{HI}_{\mathrm{o}}=40 \%$ in Iran, and Pareek et al. (2017) $\mathrm{HI}_{\mathrm{o}}$ $=34 \%$ in India. Trombetta et al. (2016) calibrated $\mathrm{HI}_{\mathrm{o}}$ $=43 \%$ for winter wheat in Rocchetta Sant'Antonio and Sant'Agata di Puglia, both in Italy. Raes et al. (2018b) pointed out that this index increases gradually from flowering onwards until reaching its reference value at physiological maturity, and that a short grain-filling stage due to early canopy senescence may cause an inadequate photosynthesis and a reduction in $\mathrm{HI}_{0}$.
The values obtained for $\mathrm{WP}^{*}$ ranged from 17 to $19 \mathrm{~g} \mathrm{~m}^{-2}$ in all locations, and the lowest value was higher than that observed by Trombetta et al. (2016) in Italy and by Zhang et al. (2013) in China (WP* = $15 \mathrm{~g} \mathrm{~m}^{-2}$ ). Moreover, the $\mathrm{WP}^{*}$ values in the present study were in the range of 15 to $20 \mathrm{~g} \mathrm{~m}^{-2}$ recommended by FAO for C3 cycle crops (Raes et al., 2018b). Toumi et al. (2016) and Bouazzama et al. (2017) found WP* values of 16.0 and $15.3 \mathrm{~g} \mathrm{~m}^{-2}$, respectively, for winter wheat in Morocco.

The $\mathrm{Kc}_{\mathrm{TR}, \mathrm{x}}$ values ranged from 1.25 to 1.37 for all cultivars and locations. Other authors obtained lower $\mathrm{Kc}_{\mathrm{TR}, \mathrm{x}}$ values for the wheat crop, as Toumi et al. (2016)

Table 4. Absolute error (AE), relative error (RE), root mean square error (RMSE), Pearson's correlation coefficient (r), and $\mathrm{d}$ and $\mathrm{c}$ indexes obtained from the association of simulated vs. observed yield in the calibration and validation processes by the AquaCrop model for wheat (Triticum aestivum) cultivars evaluated in the municipalities of Castro and Ponta Grossa, in the state of Paraná, Southern Brazil ${ }^{(1)}$.

\begin{tabular}{|c|c|c|c|c|c|c|c|c|}
\hline Location & Cultivar & $\begin{array}{c}\mathrm{AE} \\
\left(\mathrm{kg} \mathrm{ha}^{-1}\right)\end{array}$ & $\begin{array}{l}\mathrm{RE} \\
(\%)\end{array}$ & $\begin{array}{c}\text { RMSE } \\
\left(\mathrm{kg} \mathrm{ha}^{-1}\right)\end{array}$ & r & $\begin{array}{c}\mathrm{d} \\
\text {-- unit }\end{array}$ & c & Performance \\
\hline & \multicolumn{8}{|c|}{ Calibration process } \\
\hline \multirow{2}{*}{ Castro } & Supera & 233.41 & 4.68 & 329.78 & 0.85 & 0.87 & - & - \\
\hline & Quartzo & 178.18 & 4.03 & 188.67 & 0.82 & 0.88 & - & - \\
\hline \multirow{5}{*}{ Ponta Grossa } & Supera & 180.76 & 3.67 & 241.14 & 0.91 & 0.94 & - & - \\
\hline & Quartzo & 256.51 & 6.41 & 330.26 & 0.92 & 0.88 & - & - \\
\hline & TBIO Toruk & 562.63 & 11.39 & 609.78 & 0.90 & 0.90 & - & - \\
\hline & TBIO Tibagi & 148.32 & 3.33 & 150.40 & 0.90 & 0.93 & - & - \\
\hline & TBIO Sinuelo & 377.18 & 7.86 & 484.85 & 0.72 & 0.80 & - & - \\
\hline & \multicolumn{8}{|c|}{ Validation process } \\
\hline \multirow{2}{*}{ Castro } & Supera & $1,737.95$ & 31.40 & $2,159.21$ & 0.40 & 0.34 & 0.13 & Terrible \\
\hline & Quartzo & $1,209.25$ & 32.85 & $1,327.72$ & 0.11 & 0.36 & 0.04 & Terrible \\
\hline \multirow{5}{*}{ Ponta Grossa } & Supera & $1,133.59$ & 24.94 & $1,266.52$ & 0.69 & 0.67 & 0.46 & $\mathrm{Bad}$ \\
\hline & Quartzo & $1,547.37$ & 48.88 & $1,784.33$ & 0.07 & 0.31 & 0.02 & Terrible \\
\hline & TBIO Toruk & $2,563.40$ & 138.85 & $2,680.50$ & 0.06 & 0.18 & 0.01 & Terrible \\
\hline & TBIO Tibagi & $1,031.64$ & 23.63 & $1,090.81$ & 0.04 & 0.47 & 0.02 & Terrible \\
\hline & TBIO Sinuelo & $1,641.61$ & 60.56 & $1,814.87$ & 0.05 & 0.35 & 0.02 & Terrible \\
\hline \multicolumn{9}{|c|}{ Verification of calibration range } \\
\hline \multirow{2}{*}{ Castro } & Supera & 137.88 & 4.05 & 426.52 & 0.94 & 0.95 & 0.89 & Excellent \\
\hline & Quartzo & 158.26 & 3.68 & 378.07 & 0.87 & 0.92 & 0.80 & Very good \\
\hline \multirow{5}{*}{ Ponta Grossa } & Supera & 36.62 & 0.69 & 93.45 & 1.00 & 1.00 & 1.00 & Excellent \\
\hline & Quartzo & 95.10 & 4.48 & 336.67 & 0.96 & 0.98 & 0.93 & Excellent \\
\hline & TBIO Toruk & 675.17 & 42.61 & 1219.86 & 0.81 & 0.69 & 0.56 & Tolerable \\
\hline & TBIO Tibagi & 4.75 & 0.10 & 5.76 & 1.00 & 1.00 & 1.00 & Excellent \\
\hline & TBIO Sinuelo & 217.06 & 10.48 & 588.43 & 0.87 & 0.88 & 0.77 & Very good \\
\hline Castro & All cultivars & 150.11 & 3.83 & 398.16 & 0.91 & 0.95 & 0.86 & Excellent \\
\hline Ponta Grossa & All cultivars & 156.04 & 8.12 & 508.64 & 0.90 & 0.94 & 0.85 & Very good \\
\hline
\end{tabular}


$\left(\mathrm{Kc}_{\mathrm{TR}, \mathrm{x}}=1.07\right)$ for winter wheat in the semiarid region of the Tensift basin, in central Morocco. In the literature, there are also reports of $\mathrm{Kc}_{\mathrm{TR}, \mathrm{x}}=1.13$ (Bouazzama
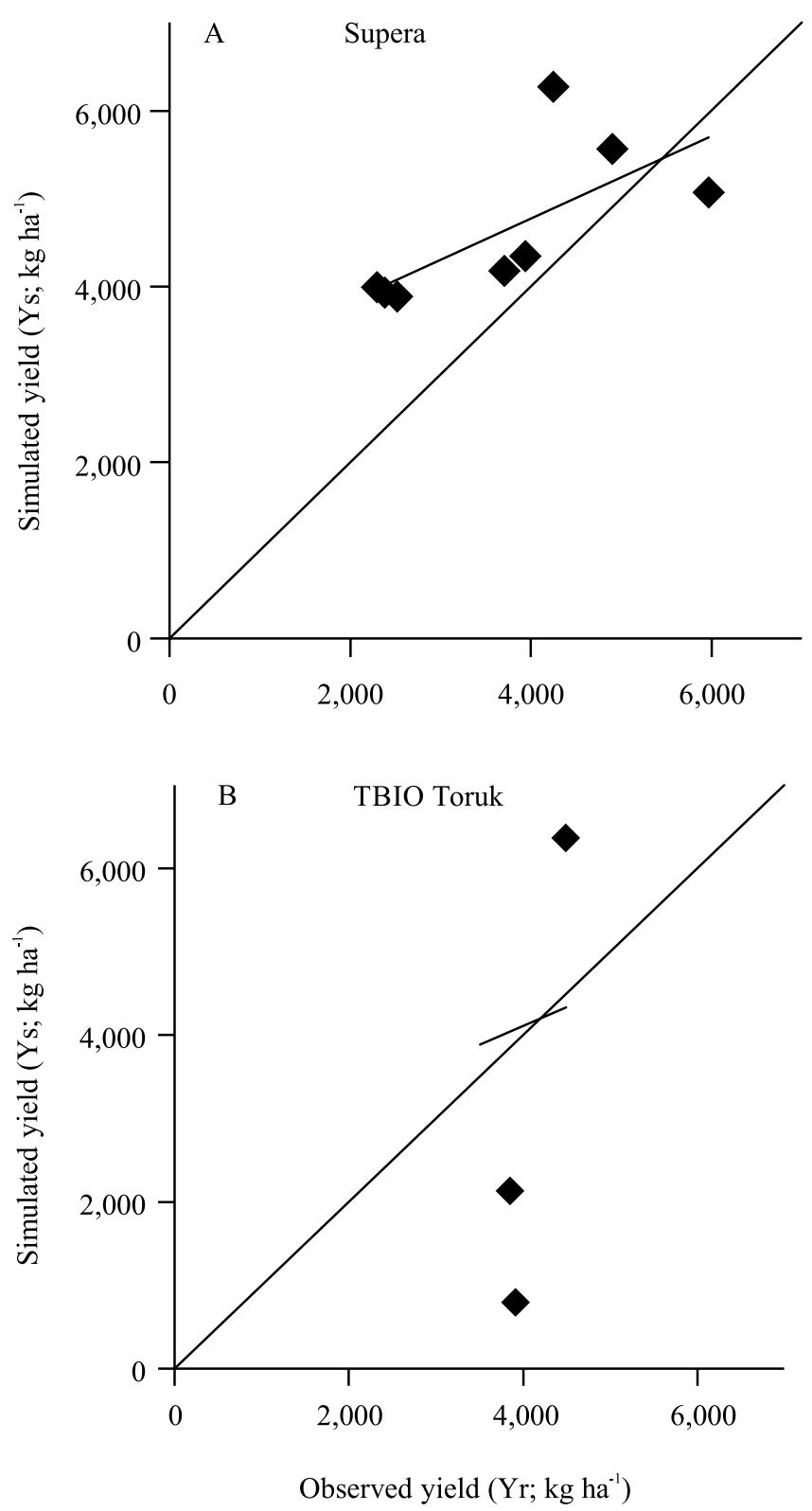

Figure 3. Linear regression analysis obtained from the association between observed vs. simulated yield in the validation process by the AquaCrop model for wheat (Triticum aestivum) cultivars, considering fixed calibration parameters. A, better analysis ("bad") for the Supera cultivar $(\mathrm{r}=0.69 ; \mathrm{d}=0.67 ; \mathrm{c}=0.46)$; and $\mathrm{B}$, worst analysis ("terrible") for the TBIO Toruk cultivar $(\mathrm{r}=0.06 ; \mathrm{d}=0.18$; $\mathrm{c}=0.01)$, in Ponta Grossa, in the state of Paraná, Southern Brazil. et al., 2017) and $\mathrm{Kc}_{\mathrm{TR}, \mathrm{x}}=1.10$ (Trombetta et al., 2016; Pareek et al., 2017).

The $\mathrm{CC}_{\mathrm{x}}$ ranged from 89 to $93 \%$ for all cultivars and locations, and the highest value was observed for the Supera cultivar in Castro. The obtained values are within the limits of 80 to $99 \%$ recommended by Raes et al. (2018a). In the literature, the $\mathrm{CC}_{\mathrm{x}}$ values due to calibration were also high and variable for winter wheat: $98.7 \%$ in different water conditions in Morocco (Bouazzama et al., 2017); 98\% in China (Xiangxiang et al., 2013); 95\% in Pantnagar, India (Pareek et al., 2017); 90 and 79\% in Rocchetta Sant'Antonio and Sant'Agata di Puglia, respectively, in Italy (Trombetta et al., 2016); and 90\% in China (Zhang et al., 2013).

The CDC, which was only evaluated in Castro, was 7.6 and $7.7 \%$ per day for the Supera and Quartzo cultivars, respectively. Xiangxiang et al. (2013) found $8.4 \%$ per day for this parameter. However, Kumar et al. (2014) observed CDC variations between 11.0 and $12.9 \%$ per day when evaluating the response of AquaCrop to parameter adjustments at different soil salinity levels in Delhi, India. Andarzian et al. (2011) obtained good results in the simulation for wheat with CDC adjusted to $6.2 \%$ per day in Iran, under conditions of maximum and minimum temperatures higher than those of the Campos Gerais region.

The validation analyzes for each cultivar and location were performed using the same parameter values obtained in calibration (Table 3), as well as protocol data on harvests from Fundação $\mathrm{ABC}$ that were not used in the calibration process.

In AquaCrop, the results for calibration were considered good (RMSE $\leq 609.78 \mathrm{~kg} \mathrm{ha}^{-1} ; \mathrm{r} \geq 0.72$; $\mathrm{d} \geq 0.80$ ) for all cultivars and locations; however, the performance of the validation process was "terrible" to "bad" (RMSE $\leq 2,680.50 \mathrm{~kg} \mathrm{ha}^{-1} ; \mathrm{r} \leq 0.69 ; \mathrm{d} \leq$ 0.67 ; $c \leq 0.46$ (Table 4). Figure 3 shows the best and worst associations between real and estimated yields, obtained in validation when considering the same fixed parameters used in calibration (Table 3 ).

Due to sensitivity, small changes in the evaluated input parameters $\left(\mathrm{CCx}, \mathrm{CDC}, \mathrm{Kc}_{\mathrm{TR}, \mathrm{x}}, \mathrm{WP}^{*}, \mathrm{HI}_{\mathrm{o}}\right.$, and minimum growing degrees required for full biomass production) considerably modified the simulated yield in AquaCrop. Therefore, using only one value for each parameter analyzed in the model to estimate crop yield under different conditions of wheat crop growth and development was not satisfactory and accurate 
for different conditions, including different times to reach the established phenological stages, different population of plants, different cultivars throughout the years, possible problems with pests and/or diseases, and climatic conditions (drought periods).

Since even small modifications in input parameters caused large changes in the simulated yield in AquaCrop, scenarios were used to test the reliability of a calibrated parameter range for the harvests (Table 3 ). It should be highlighted that the same harvests evaluated in the validation process were used in the parameter range analysis (Table 2).

The analysis of the calibrated parameter range of the harvests showed "very good" and "excellent" performances (for the Quartzo and Supera cultivars, respectively) in Castro and "tolerable" to "excellent" ones in Ponta Grossa (Table 4 and Figure 4). The results indicated that the functional relationships between the most sensitive parameters $\left(\mathrm{CCx}, \mathrm{CDC}, \mathrm{Kc}_{\mathrm{TR}, \mathrm{x}}, \mathrm{WP}^{*}\right.$, HIo, and minimum growing degrees required for full biomass production), not considered or specified in the AquaCrop options, can significantly improve the model's performance $\left(5.76 \mathrm{~kg} \mathrm{ha}^{-1} \leq \mathrm{RMSE} \leq 1,219.86\right.$ $\mathrm{kg} \mathrm{ha}^{-1} ; 0.81 \leq \mathrm{r} \leq 1.0 ; 0.69 \leq \mathrm{d} \leq 1.0 ; 0.56 \leq \mathrm{c} \leq 1.0$ ).

Some cultivars presented absolute and relative errors in validation that were larger than those found in calibration (Table 4 and Figure 4). The AquaCrop model indicated temperature stress in two harvests of the Quartzo cultivar in Castro due to 18 and 25 days of temperature below $5^{\circ} \mathrm{C}$ in each crop before flowering. According to Raes et al. (2018a), $5^{\circ} \mathrm{C}$ is the minimum air temperature below which pollination starts to fail (cold stress) in the wheat crop. Therefore, the period in which the temperature was below $5^{\circ} \mathrm{C}$ in the harvests resulted in the observed errors (Table 4).

The Quartzo cultivar in Ponta Grossa presented harvests with high water restriction at the beginning of the cycle. Only $8 \mathrm{~mm}$ of rainfall were registered in the first 35 days after planting, also reflecting the obtained statistical errors (Table 4).

The TBIO Sinuelo and TBIO Toruk cultivars also showed water deficit along the growing cycles. This limitation occurred in periods that preceded flowering, more regularly for the TBIO Toruk cultivar, resulting in the largest errors obtained in the software (Figure 4 and Table 4).

In Castro, the observed performances were "excellent" for Supera and "very good" for Quartzo
(Figure $4 \mathrm{~A}$ ), indicating that the range of parameters was suitable for the cultivars in the region. The $d$ index in Castro was similar to that found by Kumar et al. (2014) in India $(d=0.96)$ for final grain yield. Andarzian et al. (2011), studying irrigated wheat in Iran, also reported good results in the validation process $(d=0.97)$.

According to Camargo \& Sentelhas (1997), the c index resulted in a "tolerable" performance for the TBIO Toruk cultivar in Ponta Grossa, probably due to the small number of experiments used in calibration (Figure $4 \mathrm{~B}$ and Table 2). Therefore, it was not possible to adequately adjust the obtained parameters in the sensitivity and linear regression analyzes for this cultivar, impairing data interpretation. For the other cultivars, the performance of the model was satisfactory, varying between "very good" and "excellent".

Considering the statistical adjustments by the c index, the best results were obtained for the Supera and TBIO Tibagi cultivars in Ponta Grossa (Table 4), with $r$ and the $d$ and $c$ indexes equal to 1.00 (Figure 4 A, B, and C). Similar results were reported by Toumi et al. $(2016)\left(r=0.99\right.$ and $\left.\mathrm{RMSE}=100 \mathrm{~kg} \mathrm{ha}^{-1}\right)$.

The values obtained for the TBIO Sinuelo cultivar in Ponta Grossa were the closest to those found by Kale (2016) $\left(\mathrm{RMSE}=330 \mathrm{~kg} \mathrm{ha}^{-1} ; \mathrm{d}\right.$ index $\left.=0.83\right)$, which validated AquaCrop for the wheat crop considering the parameters suggested by Raes et al. (2009). Iqbal et al. (2014) also observed similar values $(\mathrm{RSME}=$ $580 \mathrm{~kg} \mathrm{ha}^{-1} ; \mathrm{d}$ index $=0.92$ ) in China.

The results of the simulated and real yield analyses used to determine the calibration range of AquaCrop, considering all analyzed cultivars (Table 4 and Figure 4 $\mathrm{C}$ ), were similar to those of the analysis performed for each cultivar (Figure $4 \mathrm{~A}$ and B). In Castro, cultivars achieved an "excellent" performance and, in Ponta Grossa, a "very good" one.

The obtained results, considering the calibrated parameter range, are very promising for future studies in the region involving the planning and simulation of agricultural scenarios. These results are also an indicative that the functional relationships between the most sensitive parameters, not considered or specified in the AquaCrop options, can significantly improve the performance of the model. 

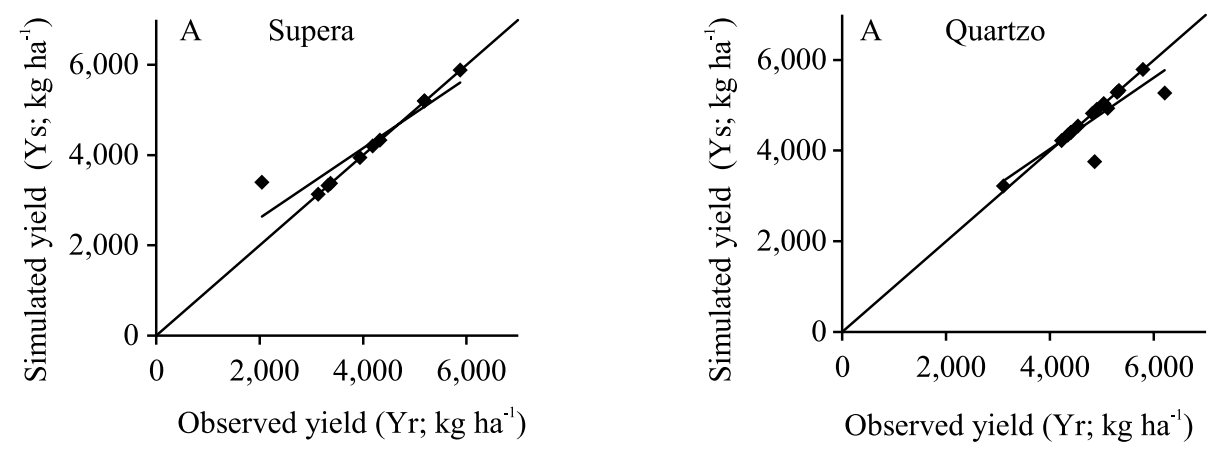

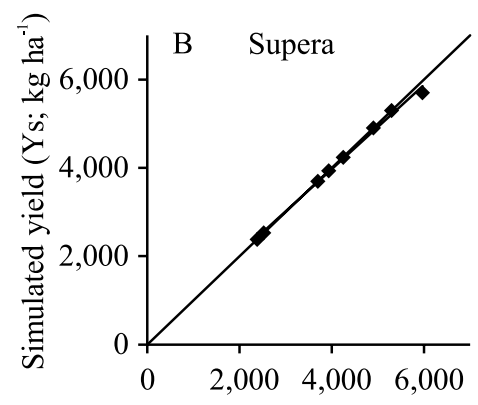

Observed yield (Yr; $\mathrm{kg} \mathrm{ha}^{-1}$ )

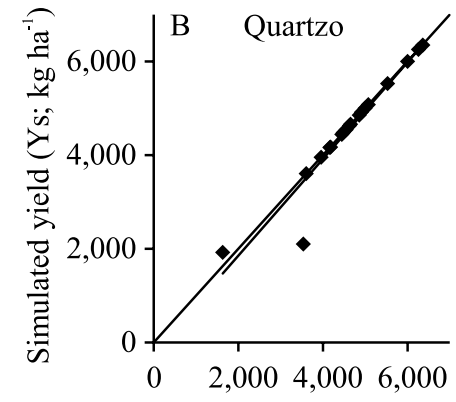

Observed yield ( $\left.\mathrm{Yr} ; \mathrm{kg} \mathrm{ha}^{-1}\right)$

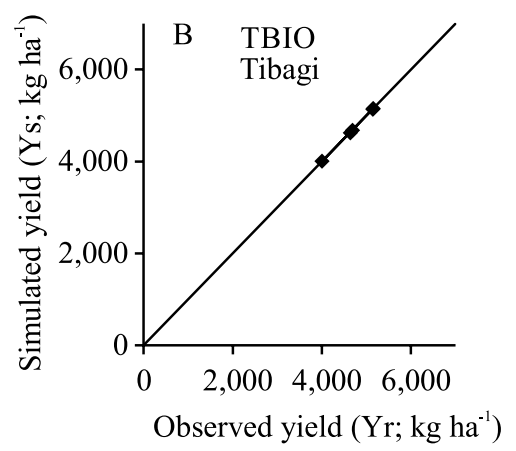

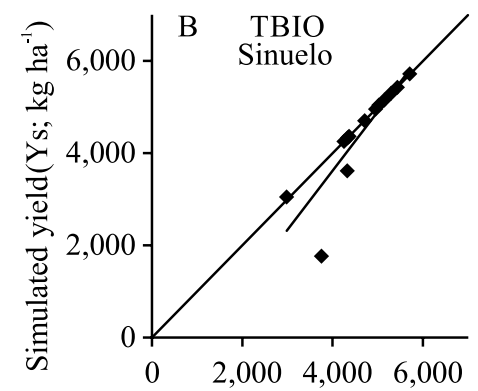

Observed yield (Yr; $\mathrm{kg} \mathrm{ha}^{-1}$ )
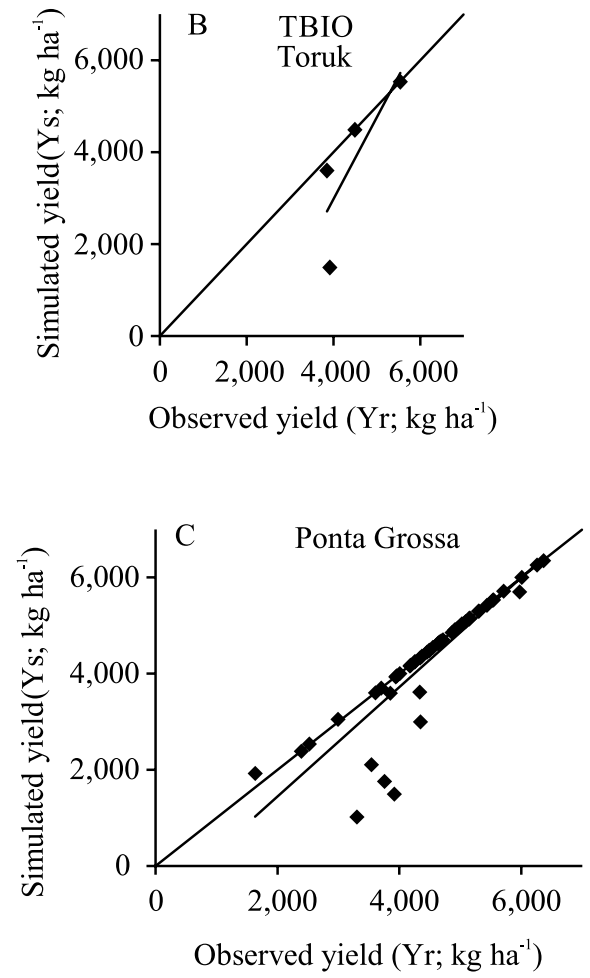

Figure 4. Linear regression analysis obtained from the association of simulated vs. observed yield in the validation process by the AquaCrop model, considering calibration ranges for: A, each cultivar evaluated in Castro; B, each cultivar evaluated in Ponta Grossa; and C, all cultivars evaluated in the municipalities of Castro and Ponta Grossa, located in the state of Paraná, Southern Brazil. 


\section{Conclusions}

1. Calibration by the AquaCrop model shows good results for all wheat (Triticum aestivum) cultivars and locations analyzed in the Campos Gerais region in Southern Brazil.

2. The attempted adjustment indicates different performances for the evaluated cultivars: "very good" for Quartzo and "excellent" for Supera in the municipality of Castro; and "tolerable" for TBIO Toruk, "very good" for TBIO Sinuelo, and "excellent" for Supera, Quartzo and TBIO Tibagi in the municipality of Ponta Grossa, in the Campos Gerais region.

\section{Acknowledgments}

To Fundação ABC Pesquisa e Desenvolvimento Agropecuário, for support in conducting field experiments.

\section{References}

AKOGLU, H. User's guide to correlation coefficients. Turkish Journal of Emergency Medicine, v.18, p.91-93, 2018. DOI: https://doi.org/10.1016/j.tjem.2018.08.001.

ALVARES, C.A.; STAPE, J.L.; SENTELHAS, P.C.; GONÇALVES, J.L. de M.; SPAROVEK, G. Köppen's climate classification map for Brazil. Meteorologische Zeitschrift, v.22, p.711-728, 2013. DOI: https://doi.org/10.1127/09412948/2013/0507.

ANDARZIAN, B.; BANNAYAN, M.; STEDUTO, P.; MAZRAEH, H.; BARATI, M.E.; BARATI, M.A.; RAHNAMA, A. Validation and testing of the AquaCrop model under full and deficit irrigated wheat production in Iran. Agricultural Water Management, v.100, p.1-8, 2011. DOI: https://doi.org/10.1016/j. agwat.2011.08.023

BOUAZZAMA, B.; KARROU, M.; BOUTFIRASS, M.; BAHRI, A. Assessment of Aquacrop model in the simulation of durum wheat (Triticum aestivum L.) growth and yield under different water regimes. Revue Marocaine des Sciences Agronomiques et Vétérinaires, v.5, p.222-230, 2017.

CAMARGO, A.P. de; SENTELHAS, P.C. Avaliação do desempenho de diferentes métodos de estimativa da evapotranspiração potencial no Estado de São Paulo, Brasil. Revista Brasileira de Agrometeorologia, v.5, p.89-97, 1997.

DARKO, R.O.; SHOUQI, Y.; HAOFANG, Y.; JUNPING, L.; ABBEY, A. Calibration and validation of AquaCrop for deficit and full irrigation of tomato. International Journal of Agricultural and Biological Engineering, v.9, p.104-110, 2016. DOI: https:// doi.org/10.3965/j.ijabe.20160903.1812.

FAO. Food and Agriculture Organization of the United Nations. Food outlook: biannual report on global food markets. Rome. 2018a. Available at: $<$ http://www.fao.org/3/CA2320EN/ca2320en. pdf $>$. Accessed on: Aug. 52018.

FAO. Food and Agriculture Organization of the United Nations. Land \& Water: AquaCrop. version 6.0. 2018b. Available at: $\quad<$ http://www.fao.org/land-water/databases-and-software/ Aquacrop/en/>. Accessed on: Mar. 32018.

FOSTER, T.; BROZIVIĆ, N.; BUTLER, A.P.; NEALE, C.M.U.; RAES, D.; STEDUTO, P.; FERERES, E.; HSIAO, T.C. AquaCropOS: an open source version of FAO's crop water productivity model. Agricultural Water Management, v.181, p.18-22, 2017. DOI: https://doi.org/10.1016/j.agwat.2016.11.015.

HE, D.; WANG, E.; WANG, J.; ROBERTSON, M.J. Data requirement for effective calibration of process-based crop models. Agricultural and Forest Meteorology, v.234-235, p.136148, 2017. DOI: https://doi.org/10.1016/j.agrformet.2016.12.015.

IQBAL, M.A.; SHEN, Y.; STRICEVIC, R.; PEI, H.; SUN, H.; AMIRI, E.; PENAS, A.; DEL RIO, S. Evaluation of the FAO AquaCrop model for winter wheat on the North China Plain under deficit irrigation from field experiment to regional yield simulation. Agricultural Water Management, v.135, p.61-72, 2014. DOI: https://doi.org/10.1016/j.agwat.2013.12.012.

JACOVIDES, C.P.; KONTOYIANNIS, H. Statistical procedures for the evaluation of evapotranspiration computing models. Agricultural Water Management, v.27, p.365-371, 1995. DOI: https://doi.org/10.1016/0378-3774(95)01152-9.

JIN, X.-L.; FENG, H.-K.; ZHU, X.-K.; LI, Z.-H.; SONG, S.-N.; SONG, X.-Y.; YANG, G.-J.; XU, X.-G.; GUO, W.-S. Assessment of the AquaCrop model for use in simulation of irrigated winter wheat canopy cover, biomass, and grain yield in the North China Plain. PLoS ONE, v.9, e86938, 2014. DOI: https://doi.org/10.1371/ journal.pone.0086938.

KALE, S. Assessment of Aquacrop model in the simulation of wheat growth under different water regimes. Scientific Papers. Series A. Agronomy, v.59, p.308-314, 2016.

KUMAR, P.; SARANGI, A.; SINGH, D.K.; PARIHAR, S.S. Evaluation of Aquacrop model in predicting wheat yield and water productivity under irrigated saline regimes. Irrigation and Drainage, v.63, p.474-487, 2014. DOI: https://doi.org/10.1002/ ird.1841

MELO, M.S. de; MORO, R.S.; GUIMARÃES, G.B. (Ed.). Patrimônio natural dos Campos Gerais do Paraná. Ponta Grossa: Ed. da UEPG, 2014. 227p. Available at: <http://www. uepg.br/editora>. Accessed on: Aug. 72019.

MONTOYA, F.; CAMARGO, D.; ORTEGA, J.F.; CÓRCOLES, J.I.; DOMÍNGUEZ, A. Evaluation of Aquacrop model for a potato crop under different irrigation conditions. Agricultural Water Management, v.164, p.267-280, 2016. DOI: https://doi. org/10.1016/j.agwat.2015.10.019.

OIGANJI, E.; IGBADUN, H.E.; MUDIARE, O.J.; OYEBODE, M.A. Calibrating and validating AquaCrop model for maize crop in Northern zone of Nigeria. Agricultural Engineering International, v.18, p.1-13, 2016.

OLIVEIRA NETO, A.A. de; SANTOS, C.M.R. A cultura do trigo. Brasília: Conab, 2017. 218p. Available at: <https://www. 
conab.gov.br/uploads/arquivos/17_04_25_11_40_00_a_cultura do_trigo_versao_digital_final.pdf >. Accessed on: Nov. 112018.

PAREEK, N.; ROY, S.; SAHA, S.; NAIN, A. Calibration \& validation of Aquacrop model for wheat crop in Tarai region of Uttarakhand. Journal of Pharmacognosy and Phytochemistry, v.6, p.1442-1445, 2017.

PIEKARSKI，K.R.; SOUZA， J.L.M.; TSUKAHARA， R.Y.; ROSA, S.L.K.; OLIVEIRA, C.T. Estimativa da produtividade da cultura da soja considerando a influência dos atributos físicohídricos do solo na região dos Campos Gerais. In: CONGRESSO ONLINE DE AGRONOMIA, 5., 2017, Road Town. Anais online. São Paulo: Instituto Pantex de Pesquisa, 2017.

RAES, D.; STEDUTO, P.; HSIAO, T.C.; FERERES, E. AquaCrop: version 6.0-6.1: Reference manual: annexes. Rome: FAO, 2018a. Available at: <http://www.fao.org/3/a-br244e.pdf $>$. Accessed on: Feb. 212018.

RAES, D.; STEDUTO, P.; HSIAO, T.C.; FERERES, E. Chapter 1: FAO crop-water productivity model to simulate yield response to water: AquaCrop: version 6.0-6.1: reference manual. Rome: FAO, 2018b. 19p.

RAES, D.; STEDUTO, P.; HSIAO, T.C.; FERERES, E. Crop water productivity. Calculation procedures and calibration guidance. Aquacrop Version 3.0. Rome: FAO, 2009.

SHIMANDEIRO, A.; KANTELHARDT, J.; WEIRICH NETO, P.H. Characterization of major crop management in the buffer zone of Vila Velha State Park, state of Paraná, Brazil. Acta Scientiarum. Agronomy, v.30, p.225-230, 2008. DOI: https://doi.org/10.4025/actasciagron.v30i2.1732.

SILVA, A.A.V. da; SILVA, I.A.F.; TEIXEIRA FILHO, M.C.M.; BUZETTI, S.; TEIXEIRA, M.C.M. Estimativa da produtividade de trigo em função da adubação nitrogenada utilizando modelagem neuro fuzzy. Revista Brasileira de Engenharia Agrícola e Ambiental, v.18, p.180-187, 2014. DOI: https://doi.org/10.1590/S1415-43662014000200008.

SILVA, V. de P.R. da; SILVA, R.A. e; MACIEL, G.F.; BRAGA, C.C.; SILVA JÚNIOR, J.L.C. da; SOUZA, E.P. de; ALMEIDA, R.S.R.; SILVA, M.T.; HOLANDA, R.M. de. Calibration and validation of the AquaCrop model for the soybean crop grown under different levels of irrigation in the Motopiba region, Brazil. Ciência Rural, v.48, e20161118, 2018. DOI: https://doi. org/10.1590/0103-8478cr20161118.

TEIXEIRA, P.C.; DONAGEMMA, G.K.; FONTANA, A.; TEIXEIRA, W.G. (Ed.). Manual de métodos de análise de solo. 3.ed. rev. e ampl. Brasília: Embrapa, 2017. 573p.

TOUMI, J.; ER-RAKI, S.; EZZAHAR, J.; KHABBA, S.; JARLAN, L.; CHEHBOUNI, A. Performance assessment of AquaCrop model for estimating evapotranspiration, soil water content and grain yield of winter wheat in Tensift Al Haouz (Morocco): application to irrigation management. Agricultural Water Management, v.163, p.219-235, 2016. DOI: https://doi. org/10.1016/j.agwat.2015.09.007.

TROMBETTA, A.; IACOBELLIS, V.; TARANTINO, E.; GENTILE, F. Calibration of the AquaCrop model for winter wheat using MODIS LAI images. Agricultural Water Management, v.164, p.304-316, 2016. DOI: https://doi.org/10.1016/j. agwat.2015.10.013.

WILLMOTT, C.J. Some comments on the evaluation of model performance. Bulletin American Meteorological Society, v.63, p.1309-1313, 1982. DOI: https://doi.org/10.1175/15200477(1982)063<1309:SCOTEO >2.0.CO;2.

XIANGXIANG, W.; QUANJIU, W.; JUN, F.; QIUPING, F. Evaluation of the AquaCrop model for simulating the impact of water deficits and different irrigation regimes on the biomass and yield of winter wheat grown on China's Loess Plateau. Agricultural Water Management, v.129, p.95-104, 2013. DOI: https://doi.org/10.1016/j.agwat.2013.07.010.

ZADOKS, J.C.; CHANG, T.T.; KONZAK, C.F. A decimal code for the growth stages of cereals. Weed Research, v.14, p.415-421, 1974. DOI: https://doi.org/10.1111/j.1365-3180.1974. tb01084.x.

ZHANG, W.; LIU, W.; XUE, Q.; CHEN, J.; HAN, X. Evaluation of the AquaCrop model for simulating yield response of winter wheat to water on the southern Loess Plateau of China. Water Science \& Technology, v.68, p.821-828, 2013. DOI: https://doi.org/10.2166/wst.2013.305. 